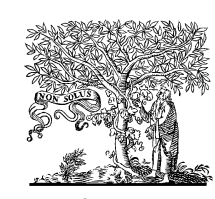

ELSEVIER

Cytokine 41 (2008) 84-91

Review Article

\title{
IL-17/Th17 targeting: On the road to prevent chronic destructive arthritis?
}

\author{
Erik Lubberts * \\ Department of Rheumatology, Erasmus Medical Center, Dr. Molewaterplein 50, 3015 GE Rotterdam, The Netherlands
}

Received 6 September 2007; received in revised form 28 September 2007; accepted 28 September 2007

\begin{abstract}
Interleukin-17A (IL-17A) contributes to the pathogenesis of arthritis. Data from experimental arthritis indicate IL-17 receptor signaling as a critical pathway in turning an acute synovitis into a chronic destructive arthritis. The identification of six IL-17 family members (IL-17A-F) may extend the role of this novel cytokine family in the pathogenesis of chronic destructive joint inflammation. Whether the successful anti-IL-17A cytokine therapy in murine arthritis can be effectively translated to human arthritis need to be tested in clinical trials in humans. Interestingly, IL-17A and IL-17F are secreted by the novel T helper subset named Th17. This novel pathogenic T cell population induces autoimmune inflammation in mice and is far more efficient at inducing Th1-mediated autoimmune inflammation in mice than classical Th1 cells (IFN- $\gamma$ ). In addition to IL-17A and IL-17F, Th17 cells are characterized by expression of IL-6, TNF, GMCSF, IL-21, IL-22 and IL-26. Th17 cells have been established as a separate lineage of T helper cells in mice distinct from conventional Th1 and Th2 cells. Whether this also applies to human Th17 and whether RA is a Th1 or a Th17 mediated disease is still not clear. This review summarizes the findings about the role of IL-17 in arthritis and discusses the impact of the discovery of the novel Th17 cells for arthritis. Further studies are needed to unravel the role of Th17 cells and the interplay of IL-17 and other Th17 cytokines in the pathogenesis of arthritis and whether regulating Th17 cell activity will have additional value compared to neutralizing IL-17A activity alone. This might help to reach the ultimate goal not only to treat RA patients but to prevent the development of this crippling disease.
\end{abstract}

(C) 2007 Elsevier Ltd. All rights reserved.

Keywords: Autoimmunity; Cytokine; Th17 cell; Inflammation; Interleukin-17

\section{Introduction}

Rheumatoid arthritis (RA) is a chronic systemic disorder characterized by autoimmunity, infiltration of joint synovium by activated inflammatory cells, synovial hyperplasia, neoangiogenesis, and progressive destruction of cartilage and bone. This disease affects $1-2 \%$ of the population worldwide, most commonly middle-aged women. The etiology of RA is unknown but pro-inflammatory cytokines play a central role in RA. Regulation of the cytokine disbalance might represent a solid way to control this disease. The pro-inflammatory cytokines TNF $\alpha$ and IL-1 play a crucial role in the pathogenesis of arthritis, driving

\footnotetext{
${ }^{*}$ Corresponding author. Fax: +31 104635688.

E-mail address: e.lubberts@erasmusmc.nl
}

enhanced production of cytokines, chemokines, and degradative enzymes [1]. Clinical studies revealed efficacy after blocking TNF $\alpha$. However, a subset of patients does not respond to anti-TNF and this treatment does not cure the disease. Therefore, cytokines or factors other than IL1 and TNF $\alpha$ may also participate in the pro-inflammatory cytokine cascade.

$\mathrm{T}$ cells represent a large proportion of the inflammatory cells invading the synovial tissue. $\mathrm{T}$ cell activation and migration into the synovium occurs as an early consequence of disease, and these cells adopt a pro-inflammatory phenotype. Considerable evidence now supports a role for $\mathrm{T}$ cells in the initiation and perpetuation of the chronic inflammation prevalent in RA. Interestingly, the vast majority of these are (memory) $\mathrm{T}$ cells producing IL-17 that is up-regulated in early disease and is thought to contribute to the inflammation associated with RA $[2,3]$. 


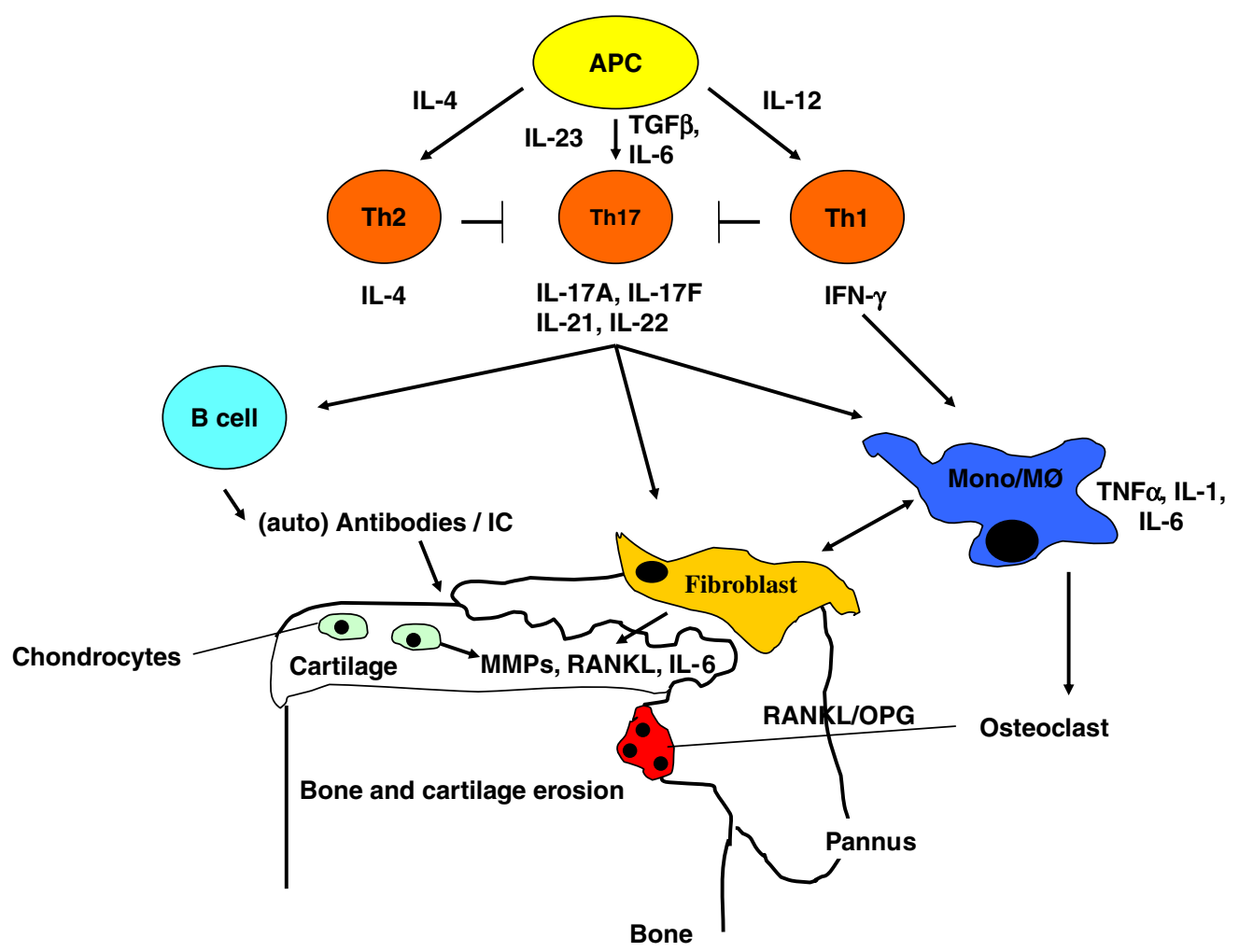

Fig. 1. Schematic overview of the role of IL-17/Th17 in relation with other key cytokines and the cellular pathways of synovitis and concomitant joint destruction. Is RA a Th1 or Th17 mediated disorder?

IL-17A induces the production of pro-inflammatory mediators, such as IL-1 and TNF $\alpha$ from several joint cells including synovial fibroblast, macrophages, and chondrocytes [4-7] (Fig. 1). In addition, IL-17A induces receptor activator of NF- $\mathrm{KB}$ ligand (RANKL) expression that is crucial for osteoclastogenesis and bone resorption (Fig. 1). IL-17A can synergize with these cytokines (IL-1, TNF, RANKL), but has direct activity as well. Furthermore IL-17A is able to promote cartilage destruction and bone erosion in experimental arthritis [8,9]. When IL-17A is combined with other cytokines, already thought to be important in arthritic disease, even more marked tissue destruction occurs (10, Lubberts unpublished observations). Moreover, IL-17 receptor signaling has been identified as a critical pathway in turning an acute synovitis into a chronic destructive arthritis [11]. These observations strongly implicate IL-17A as an important mediator of arthritis.

\section{Role of IL-17A in the pathogenesis of arthritis}

\subsection{Human studies}

IL-17 is spontaneously produced by RA synovial membrane cultures and IL-17-producing cells were found in the $\mathrm{T}$ cell-rich area [2] and high levels have been detected in the synovial fluid of patients with RA [2,12]. Although bioactive IL-17 is detected in RA and osteoarthritis (OA) synovial fluid, the levels of IL-17 were found to be higher in RA synovial fluid when compared with osteoarthritis (OA) synovial fluid $[2,13]$. Th1/Th0, but not Th2 subsets of $\mathrm{CD} 4+\mathrm{T}$ cell clones isolated from rheumatoid synovium produced IL-17 [14]. IL-17 stimulates transcriptional NF$\kappa \mathrm{B}$ activity and IL-6 and IL-8 secretion in fibroblastic, endothelial, and epithelial cells, and induces $\mathrm{T}$ cell proliferation $[5,6]$. Furthermore, it triggers human synoviocytes to produce GM-CSF, and PGE2 [6], suggesting that IL-17 could be an upstream mediator in the pathogenesis of arthritis and may play a role in fine-tuning the inflammatory response. Furthermore, T cell IL-17 stimulates the production of IL-1 and TNF $\alpha$ from human macrophages in vitro [7]. It enhances IL-1-mediated IL-6 production by RA synoviocytes in vitro as well as TNF $\alpha$-induced synthesis of IL-1, IL-6 and IL-8 $[15,16]$. This indicates that IL17 synergize with IL-1 and TNF and it has been shown that the combination of TNF $\alpha$ blockade with IL-1 and IL-17 blockade is more effective for controlling IL-6 production in RA synovium cultures [10]. In addition, IL-17 induced the expression of receptor activator of $\mathrm{NF}-\mathrm{\kappa B}$ ligand (RANKL) in cultures of osteoblasts [13]. Furthermore, in vitro studies showed the induction of metalloproteinases by IL-17 in synoviocytes and chondrocytes [17-19]. Interestingly, patients with early inflammatory arthritis who subsequently developed RA had a distinct but transient synovial fluid cytokine profile [3]. The levels of a range of $\mathrm{T}$ cell, macrophage and stromal cell related cytokines (e.g. IL-2, IL-4, IL-13, IL-17, IL-15, basic fibroblast growth factor and epidermal growth factor) were 
significantly elevated in these patients within 3 months after symptom onset [3]. In addition, this profile was no longer present in established RA. In contrast, patients with non-rheumatoid persistent synovitis exhibited elevated levels of IFN- $\gamma$ at initiation [3]. In a 2-year prospective study, multivariate analysis by several different methods consistently demonstrated that synovial membrane mRNA levels of IL-1 $\beta$, TNF $\alpha$, IL-10 and IL-17 were predictive of damage progression [20]. IL-17 was synergistic with TNF $\alpha$. TNF and IL-17 effects were most pronounced with shorter disease duration, and IL-1 $\beta$ effects were more pronounced with longer disease duration. IFN- $\gamma$ was protective [20].

These data indicate that IL-17 is involved in early RA development and joint destruction which is in line with data from animal studies (Table 1). Furthermore, different processes seem to be involved in early and late stage of RA pathogenesis. Further insight in the critical cell type(s) and cytokine interplay in the initial stage of RA development may further improve RA therapy.

\subsection{Experimental arthritis studies}

In vivo animal studies revealed a critical role for IL-17 in the spontaneous development of destructive arthritis in mice deficient in IL-1 receptor antagonist since crossing IL-1ra deficient mice with IL-17 deficient mice results in complete prevention of arthritis [21]. CIA was also mark- edly although not completely suppressed in IL-17-deficient mice [22] showing a lower collagen-specific $\mathrm{T}$ cell response and collagen-specific IgG2a production. IL-17 receptor signaling was essential in turning an acute synovitis into a chronic destructive arthritis and a critical role for IL-17R signaling in late-phase neutrophilia in the joint during progressive synovitis was shown [11]. Early neutralization of endogenous IL-17 using the IL-17 receptor IgG1 Fc fusion protein during the initial phase of arthritis suppresses the onset of experimental arthritis $[8,23]$. Interestingly, a therapeutic effect of anti-IL-17 cytokine therapy in collagen arthritis was noted, implying that the T cell cytokine IL17 not only plays a role in the early stage of arthritis, but also has a function in propagating and prolongation of the arthritis [24].

In addition to joint inflammation, IL-17 has clear catabolic effects on cartilage and bone [25-28,29,30]. Studies in IL-17 receptor knockout mice revealed a critical role of IL17 receptor signaling in driving synovial expression of proinflammatory and catabolic mediators, such as IL-1 and different MMPs leading to less cartilage damage and bone erosion in experimental arthritis [11,31]. Similar as for joint inflammation, additive/synergistic catabolic effects were noted between IL-17 and IL-1/TNF [29,32,33]. In vitro, IL-17 suppresses matrix synthesis by articular chondrocytes through enhancement of nitric oxide (NO) production [26,34-36]. However, it has been shown that the

Table 1

Overview of the role of IL-17A in human and mouse studies of arthritis

\begin{tabular}{|c|c|c|}
\hline & Human studies & Mouse studies \\
\hline IL-17 expression & Spontaneously produced by RA synovium/synovial fluid $[2,12]$ & Locally in synovium of arthritic mice $[8,11]$ \\
\hline $\begin{array}{l}\text { IL-17 in } \\
\text { inflammation }\end{array}$ & $\begin{array}{l}\text { IL-17 stimulates IL-6 and IL-8 in fibroblast, endothelial and } \\
\text { epithelial cells [5,6] } \\
\text { IL-17 stimulates TNF, IL-1 in macrophages [7] } \\
\text { IL-17 stimulates GM-CSF, PGE2 in synoviocytes [6] }\end{array}$ & $\begin{array}{l}\text { IL-17 induces synovial pro-inflammatory cytokines and } \\
\text { chemokines such as TNF, IL-1, IL-6, RANKL, KC, LIX [11,33] } \\
\text { Strong inducer of neutrophil recruitment through chemokine } \\
\text { release }[8,9,33,78]\end{array}$ \\
\hline $\begin{array}{l}\text { IL-17 in early } \\
\text { arthritis }\end{array}$ & $\begin{array}{l}\text { Distinct but transient synovial fluid cytokine profile, } \\
\text { including IL-17 [3] } \\
\text { IL-17 and TNF most pronounced with shorter disease } \\
\text { duration [20] }\end{array}$ & $\begin{array}{l}\text { Lack of IL-17 activity prevents development of CIA }[8,22-24] \\
\text { and prevents spontaneous development of arthritis }[21]\end{array}$ \\
\hline $\begin{array}{l}\text { IL-17 in } \\
\text { established } \\
\text { arthritis }\end{array}$ & $\begin{array}{l}\text { Synovial expression of IL-17, IL-1, TNF, IL-10 [20] } \\
\text { IL-1 more pronounced with longer disease duration [20] } \\
\text { IFN- } \gamma \text { protective }[20]\end{array}$ & $\begin{array}{l}\text { Blocking IL-17 prevents progression of late stage CIA [24] and } \\
\text { flare-up of experimental arthritis }[11,31,33]\end{array}$ \\
\hline $\begin{array}{l}\text { IL-17 and } \\
\text { interplay with } \\
\text { TNF and IL-1 }\end{array}$ & $\begin{array}{l}\text { Enhances IL-1 mediated IL- } 6 \text { in RA synoviocytes as well } \\
\text { as TNF-induced synthesis of IL-1, IL-6, IL- } 8[15,16] \\
\text { IL-17 synergize with IL-1, TNF }[10,20,32]\end{array}$ & $\begin{array}{l}\text { IL-17 additative/synergistic effect with TNF or IL-1 [33] } \\
\text { IL-17 effect is TNF dependent under naïve conditions, but TNF } \\
\text { independent under arthritis conditions [38] } \\
\text { IL-17 effect is IL-1 independent in experimental arthritis [8,37] }\end{array}$ \\
\hline $\begin{array}{l}\text { IL-17 in bone } \\
\text { damage }\end{array}$ & $\begin{array}{l}\text { IL-17 induces RANKL in cultures of osteoblasts [13] } \\
\text { Synergy between IL-17 and TNF }[20,25,32]\end{array}$ & $\begin{array}{l}\text { IL- } 17 \text { induces bone damage in naïve mice, aggravates bone } \\
\text { erosion in CIA [44] } \\
\text { IL-17-induced bone erosion is RANKL mediated [44] }\end{array}$ \\
\hline $\begin{array}{l}\text { IL-17 in cartilage } \\
\text { damage }\end{array}$ & $\begin{array}{l}\text { IL-17 induces NO [34], metalloproteinases in synoviocytes } \\
\text { and chondrocytes [17-19] } \\
\text { Synergy between IL-17 and TNF [29] }\end{array}$ & $\begin{array}{l}\text { Inducer of NO and MMPs and inhibition of PG synthesis [26], } \\
\text { aggravates cartilage erosion in CIA }[8,9] \\
\text { IL-1 independent role of IL-17 in cartilage damage }[8,19,28]\end{array}$ \\
\hline Th17 & $\begin{array}{l}\text { IL-17-producing cells in the synovium of RA patients } \\
\text { (Th0/Th1 but not Th2) [14] }\end{array}$ & $\begin{array}{l}\text { IL-17-producing cells and Th17 in CIA and AIA arthritis } \\
\text { models }[55,60,70]\end{array}$ \\
\hline
\end{tabular}


effects of IL-17 on matrix degradation and synthesis were not dependent on IL-1 production by chondrocytes and IL-1Ra did not block IL-17-induced matrix release nor prevented inhibition of matrix synthesis in vitro using porcine articular cartilage explants [28]. On the other hand, the IL17 induced production of prostaglandin E2 (PGE2) and nitric oxide (NO) by cartilage explants is LIF-dependent $[28,36]$. Interestingly, an IL-1-independent role of IL-17 in the pathogenesis of experimental arthritis was demonstrated and IL-17 has the capacity to replace the catabolic function of IL-1 in cartilage damage during experimental arthritis [8,37]. Moreover, IL-17 acts independently of TNF under arthritis conditions with no direct role for IL-1 [38]. The downstream signaling pathways for IL-17 and IL-1 seem to be distinct and differential activation of AP-1 members by IL-17 and IL-1 $\beta$ has been described [39]. This underscores the potential of IL-17 to act additively or even synergistically with IL-1/TNF, but IL-17 may have direct catabolic effects as well.

Interestingly, the IL-17 family subtypes IL-17F and IL$17 \mathrm{E}$ also showed cartilage destructive potential in vitro $[28,40]$. Another IL-17 family member, IL-17B, has been shown to be expressed by chondrocytes in normal bovine articular cartilage, mostly in the mid and deep zones [41]. No functional studies with IL-17B have been reported.

Regulation of IL-17 and RANKL, as shown by IL-4 gene therapy in collagen arthritis, prevents osteoclastogenesis, bone erosion and cartilage destruction [42,43]. Early neutralization of IL-17 using sIL-17R:Fc fusion protein given systemically starting before arthritis expression in experimental arthritis prevented bone erosion $[8,23]$. On the other hand, local IL-17 overexpression in the knee joint of type II collagen-immunized mice results in promotion of collagen arthritis and aggravates joint destruction [9]. In the collagen-induced arthritis model it was shown that IL-17 promoted bone erosion through loss of the RANKL/OPG balance [44]. Systemic OPG treatment prevented joint damage induced by local IL-17 gene transfer in type II collagen-immunized mice. This strongly suggests that IL-17 is a potent inducer of RANKL and that the IL-17-induced promotion of bone erosion is strongly mediated by RANKL.

These studies strongly argue to target IL-17A in patients with RA (Table 1). The first clinical trials of blocking IL-17 in patients with RA are ongoing. This will learn us whether or not the successful anti-IL-17A cytokine therapy in murine arthritis can be effectively translated to human arthritis. The timing at what stage in the arthritis process IL-17A will be neutralized may be critical for the success of antiIL-17A therapy $[3,20,33]$.

\section{What is the most physiologically relevant target of IL-17A in arthritis?}

IL-17 mediates inflammation and tissue destruction through a receptor (IL-17R) composed of two subunits, IL-17RA and IL-17RC [45]. The IL-17R is a type I trans- membrane protein with no sequence similarity with any other known cytokine receptor [5]. IL-17F was reported to employ IL-17R for signaling and IL-17F and IL-17A could induce IL-17R ubiquitination and DN-TRAF6, a dominant-negative mutant, could block IL-17F but not IL-17A triggered ubiquitination of IL-17R [46]. The IL$17 \mathrm{R}$ is ubiquitously expressed in virtually all cells and tissue and its expression was shown on synoviocytes, chondrocytes and synovial endothelial cells [47-49]. Expression of different IL-17 homologs (IL-17A, C, E and $\mathrm{F}$ ) was detected in synovial fluid mononuclear cells from RA patients and different IL-17R (IL-17RA, IL$17 \mathrm{RB}, \mathrm{C}$ and $\mathrm{D})$ expression was noted in fibroblast-like synoviocytes of RA patients [50]. Effects of IL-17 on many cells have been reported including fibroblast, monocytes, osteoblast, endothelial cells and chondrocytes [6,7,32,33]. Since the IL-17R is expressed on many cell types the question arise what is the (most) relevant target for IL-17 signaling in inducing chronic inflammatory joint disease. Bone marrow chimeric mice revealed the need for IL-17R expression on radiation-resistant joint cells for destructive joint inflammation [11]. Chimeric mice of host wt and donor IL-17R-/- bone marrow (BM) cells developed destructive synovitis after repeated injection of bacterial cell wall fragments in the joint similar to $\mathrm{wt} \rightarrow \mathrm{wt}$ chimeras. In contrast, chimeric mice of host IL-17R -/- and donor wt BM cells were protected from chronic destructive arthritis similar as IL-17R $-/-\rightarrow$ IL-17R $-/-$ chimeras. In these chimeras a high degree of chimerism in myeloid cells with $>90 \%$ engraftment in peripheral blood was achieved. No difference in IL-17-positive cells in these four groups of BM chimeric mice was noted suggesting that IL-17R signaling between dendritic cells and $\mathrm{T}$ cells is not necessary for IL-17 production. To speculate about the origin of these radiation-resistant cell types, fibroblast-like synoviocytes, synovial macrophages as well as endothelial cells are potential candidates. During arthritis, IL-17R positive cells are fibroblast-like cells, chondrocytes, mononuclear cells, endothelial cells, bone lining cells, and many polymorphonuclear cells [11]. Further studies in cell-type specific IL-17R knockout/knockin mice are needed to fully identify the most relevant IL-17 responding cell type(s) that are critical in the IL-17-induced chronic inflammatory arthritis process.

\section{Th17 cells/Th17 cytokines in arthritis}

Recently a novel pathogenic $\mathrm{T}$ cell population (Th17 cells) has been identified which induces autoimmune inflammation in mice [51]. These cells are far more efficient at inducing Th1-mediated autoimmune inflammation in mice than classical Th1 cells (IFN- $\gamma$ ). First it was shown that Th17 cells were induced by a novel member of the IL-12 (p35/p40) family, IL-23 (p19/p40). Dendritic cells (DC) secrete cytokines of the IL-12 family such as IL-12 and IL-27 (p28/p40) and play a role in Th1 cell proliferation and activation leading to the production of IFN- $\gamma$. 
IL-23 induces the differentiation of naive T cells into Th17 cells through a mechanism distinct from the signals driving the development of Th1 cells and Th2 cells. Neutralization of both IFN- $\gamma$ and IL-4 has been found to favor IL-23induced IL-17-producing cells [52,53]. In addition, IL-23 is required for in vivo development of Th17 cell-mediated diseases such as EAE and CIA [51,54,55]. However, later it became clear that IL-23 can not drive de novo Th17 cell differentiation from naïve CD4+ $\mathrm{T}$ cells in vitro [56]. Instead, de novo Th17 cell differentiation is driven by the combination of IL- 6 and transforming growth factor- $\beta 1$ (TGF- $\beta 1$ ) [56-58]. During development induced by IL-6 and TGF- $\beta$, Th17 cells become responsive to IL-23 and IL-23 subsequently serves as a survival factor for committed Th17 cells [56]. However, it matters whether IL-23 is present in addition to TGF- $\beta$ and IL- 6 regarding the cytokine profile expressed by Th17 cells [59,60]. Recently, a new player is added to this concept through the finding that Th17 cells produce IL-21, which creates an amplification loop for further generation of Th17 cells $[61,62]$. Th17 cells are characterized by the expression of IL-17 (IL-17A) and also reportedly express IL-17F, IL-6, tumor necrosis factor (TNF), granulocyte-macrophage colony-stimulating factor (GM-CSF), IL-21, IL-22 and in humans also IL-26 but neither interferon- $\gamma($ IFN- $\gamma)$ nor IL-4 [51-53,59,61-66]. In mice, Th17 cells have been established as a separate lineage of $\mathrm{T}$ helper cells distinct from conventional Th1 and Th2 cells $[52,53]$. Transcription factors and signaling molecules that are important for the differentiation of Th1 or Th2 cells, including STAT1,4,6 (signal transducers and activators of transcription) and T-bet, are dispensable for the development of Th17 cells [52,53]. Recently, ROR $\gamma$ t was discovered as a novel Th17 transcription factor [67]. Moreover, Th1 cytokines (IFN- $\gamma$, IL-12, IL-27) and Th2 cytokines (IL-4, IL13) repress Th17 cell development $[52,53,68,69]$. T cell specific overexpression of GATA3, a Th2 specific transcription factor, prevented Th17 polarization accompanied with suppression of chronic joint inflammation and bone destruction [70].

Human Th17 (hTh17) cells are identified as bearing a CCR2+CCR5- phenotype [71]. Furthermore, expression of CCR6 and CCR4 together identified human memory CD4 $+\mathrm{T}$ cells selectively producing IL-17 and expressing mRNA encoding the human ortholog of mouse ROR $\gamma \mathrm{t}$, whereas CCR6 and CXCR3 identified Th1 cells producing IFN- $\gamma$ and $\mathrm{T}$ helper cells producing both IFN- $\gamma$ and IL-17 [72]. Therefore, selective markers for human Th17 cells may help us to understand the pathogenic role of this intriguing new $\mathrm{T}$ cell subset. Interestingly, the identification of a subset of cells sharing features of both human Th1 and human Th17, which can arise from the modulation of hTh17 cells by IL-12, raises new issues concerning development and/or functional relationship between Th17 and Th1 [73].

Since IL-17A is a $\mathrm{T}$ cell factor produced by the novel Th17 subset, the question rises whether RA is a Th1 or a Th17 associated disorder (Fig. 1). On the other hand, a developmental and/or functional relationship between Th17 and Th1 [73] may be relevant for RA since IL-17 is produced by some pro-inflammatory Th1/Th0 cells isolated from synovial membranes and synovial fluid of RA patients $[14,74]$ and IL-17 co-expresses with TNF and GM-CSF in patients with Lyme arthritis [63]. Further studies are needed to clarify the $\mathrm{hTh} 1 / \mathrm{hTh} 17$ relationship in chronic arthritis. In line with these human studies, single IL-17 and IFN- $\gamma$ as well as double IL-17/IFN- $\gamma$ positive cells were noted in mice immunized with type II collagen (55, Lubberts et al. unpublished observations). Furthermore, the highly self-reactive $\mathrm{T}$ cells produced in mice as a result of genetically altered thymic $\mathrm{T}$ cell selection spontaneously differentiate into IL-17-secreting CD4+ T helper cells, which mediate an autoimmune arthritis that clinically and immunologically resembles RA [75]. Deficiency of either IL-17 or IL-6 completely inhibited arthritis development, whereas IFN- $\gamma$ deficiency exacerbated arthritis. However, the generation, differentiation, and persistence of arthritogenic Th17 cells per se were insufficient for producing overt autoimmune arthritis [75]. In line with the important role of $\mathrm{IL}-17$ in bone erosion via RANKL, Th17 cells express membrane bound RANKL and play an important role in the bone destruction phase of autoimmune arthritis [76].

Th17 cells may play a critical role in chronic destructive arthritis as well as other chronic inflammatory diseases. Specific depletion of this autoimmune driven T cell subset may be more effective as a therapy than blocking IL-12, IL-23 or IL-17 alone. In addition, it is expected that specific depletion of Th17 cells will keep the IL-12/Th1 immune pathway intact, which is an effective pathway for targeting many intracellular microbial infections and is important for the IFN- $\gamma$ production that is required to resolve these infections. On the other hand, the role of the IL-23/IL-17 axis is less clear but it seems to be limited in immunity to intracellular pathogens and is more evident in the absence of IL-12 [77,78].

\section{Conclusion}

RA is a chronic disorder with unknown etiology, characterized by autoimmunity and progressive destruction of cartilage and bone. In vitro and data from experimental arthritis models indicate IL-17 as an important player in the pathogenesis of arthritis. The identification of six IL17 family members (IL-17A-F) may extend the role of this novel cytokine family in the pathogenesis of chronic destructive joint inflammation [79]. IL-17A is a potent inducer of RANKL and demonstrates additive or even synergistic effects with IL-1 and TNF in inducing joint pathology. However, IL-17A has the capacity to induce chronic destructive arthritis in an IL-1 and TNF independent way. Whether the successful anti-IL-17A cytokine therapy in murine arthritis can be effectively translated to human arthritis need to be tested in clinical trials in humans. Interestingly, IL-17A and IL-17F are secreted by the novel T 
helper subset named Th17 cells. This novel pathogenic T cell population induces autoimmune inflammation in mice. Th17 cells are far more efficient at inducing Th1-mediated autoimmune inflammation in mice than classical Th1 cells $($ IFN- $\gamma)$. Whether this also accounts for human Th17 and whether RA is a Th1 or a Th17 mediated disease is still not clear.

The majority of patient's newly presenting arthritis have a self-limiting disease $(60 \%)$, while $40 \%$ proceed to a chronic arthritis from which $62 \%$ will develop chronic destructive arthritis (RA) [80]. Different processes and cytokine interactions seem to be involved in early and late stage of RA pathogenesis. IL-17 has been shown to be involved in the early RA development and joint destruction. From experimental arthritis studies we know that IL-17 receptor signaling is critical in turning an acute synovitis into a chronic destructive arthritis. Therefore, it is tempting to speculate that regulating/targeting the IL-17/ Th17 immune pathway may improve RA therapy. Further studies are needed to unravel the role of Th17 and the interplay of IL-17A and other Th17 cytokines in the pathogenesis of arthritis and whether regulating/targeting Th17 cells will have additional value compared to neutralizing IL-17A activity alone. This might lead to the road to reach the ultimate goal and that is to prevent the development of this crippling disease.

\section{References}

[1] Arend WP, Dayer J-M. Inhibition of the production and effects of interleukin-1 and tumor necrosis factor alpha in rheumatoid arthritis. Arthritis Rheum 1995;38:151-60.

[2] Chabaud M, Durand JM, Buchs N, Fossiez F, Page G, Frappart L, Miossec P. Human interleukin-17: a T cell-derived proinflammatory cytokine produced by the rheumatoid synovium. Arthritis Rheum 1999;42:963-70.

[3] Raza K, Scheel-Toellner D, Lee CY, Pilling D, Curnow SJ, Falciani F, Trevino V, Kumar K, Assi LK, Lord JM, Gordon C, Buckley CD, Salmon M. Synovial fluid leukocyte apoptosis is inhibited in patients with very early rheumatoid arthritis. Arthritis Res Ther 2006;8:R120.

[4] Yao Z, Painter SL, Fanslow WC, Ulrich D, Macduff BM, Spriggs MK, Armitage RJ. Human IL-17: a novel cytokine derived from T cells. J Immunol 1995;155:5483-6.

[5] Yao Z, Fanslow WC, Seldin MF, Rousseau A-M, Painter SL, Comeau MR, Cohen JI, Spriggs MK. Herpesvirus Saimiri encodes a new cytokine, IL-17, which binds to a novel cytokine receptor. Immunity 1995;3:811-21.

[6] Fossiez F, Djossou O, Chomarat P, Flores-Romo L, Ait-Yahia S, Maat C, Pin J-J, Garrone P, Garcia E, Saeland S, Blanchard D, Gaillard C, Mahapatra BD, Rouvier E, Golstein P, Banchereau J, Lebecque S. T cell interleukin-17 induces stromal cells to produce proinflammatory and hematopoietic cytokines. J Exp Med 1996;183:2593-603.

[7] Jovanovic DV, DiBattista JA, Martel-Pelletier J, Jolicoeur FC, He Y, Zhang M, Mineau F, Pelletier J-P. IL-17 stimulates the production and expression of proinflammatory cytokines, IL-1beta and TNFalpha, by human macrophages. J Immunol 1998;160:3513-21.

[8] Lubberts E, Joosten LAB, Oppers B, Van den Bersselaar L, Coenende Roo CJ, Kolls JK, Schwarzenberger P, Van de Loo FA, Van den Berg WB. IL-1-independent role of IL-17 in synovial inflammation and joint destruction during collagen-induced arthritis. J Immunol 2001;167:1004-13.
[9] Lubberts E, Joosten LAB, Van de Loo FA, Schwarzenberger P, Kolls JK, Van den Berg WB. Overexpression of IL-17 in the knee joint of collagen type II immunized mice promotes collagen arthritis and aggravates joint destruction. Inflam Res 2002;51:102-4.

[10] Chabaud M, Miossec P. The combination of tumor necrosis factor alpha blockade with interleukin-1 and interleukin-17 blockade is more effective for controlling synovial inflammation and bone resorption in an ex vivo model. Arthritis Rheum 2001;44:1293-303.

[11] Lubberts E, Schwarzenberger P, Huang W, Schurr JR, Peschon JJ, van den Berg WB, Kolls JK. Requirement of IL-17 receptor signaling in radiation-resistant cells in the joint for full progression of destructive synovitis. J Immunol 2005;175:3360-8.

[12] Ziolkowska M, Koc A, Luszczykiewics G, Ksiezopolska-Pietrzak K, Klimczak E, Chwalinska-Sadowska H, Maslinski W. High levels of IL-17 in rheumatoid arthritis patients: IL-15 triggers in vitro IL-17 production via cyclosporin A-sensitive mechanism. J Immunol 2000; $164: 2832-8$.

[13] Kotake S, Udagawa N, Takahashi N, Matsuzaki K, Itoh K, Ishiyama S, Saito S, Inoue K, Kamatani N, Gillespie MT, Martin TJ, Suda T. IL-17 in synovial fluids from patients with rheumatoid arthritis is a potent stimulator of osteoclastogenesis. J Clin Invest 1999; 103:1345-52.

[14] Aarvak T, Chabaud M, Miossec P, Natvig JB. IL-17 is produced by some proinflammatory $\mathrm{Th} 1 / \mathrm{Th} 0$ cells but not by Th2 cells. J Immunol 1999;162:1246-51.

[15] Katz Y, Nadiv O, Beer Y. Interleukin-17 enhances tumor necrosis factor alpha-induced synthesis of interleukin 1, 6, and 8 in skin and synovial fibroblasts: a possible role as a "fine-tuning cytokine" in inflammation processes. Arthritis Rheum 2001;44:2176-84.

[16] Chabaud M, Fossiez F, Taupin JL, Miossec P. Enhancing effect of IL-17 on IL-1-induced IL-6 and leukemia inhibitory factor production by rheumatoid arthritis synoviocytes and its regulation by Th2 cytokines. J Immunol 1998;161:409-14.

[17] Chabaud M, Garnero P, Dayer JM, Guerne PA, Fossiez F, Miossec P. Contribution of interleukin 17 to synovium matrix destruction in rheumatoid arthritis. Cytokine 2000;12:1092-9.

[18] Benderdour M, Tardif G, Pelletier JP, Di Battista JA, Reboul P, Ranger P, Martel-Pelletier J. Interleukin 17 (IL-17) induces collagenase-3 production in human osteoclastic chondrocytes via AP-1 dependent activation: differential activation of AP-1 members by IL17 and IL-1beta. J Rheum 2002;29:1262-72.

[19] Koshy PJ, Henderson N, Logan C, Life PF, Cawston TE, Rowan AD. Interleukin 17 induces cartilage collagen breakdown: novel synergistic effects in combination with proinflammatory cytokines. Ann Rheum Dis 2002;61:704-13.

[20] Kirkham BW, Lassere MN, Edmonds JP, Juhasz KM, Bird PA, Lee CS, Shnier R, Portek IJ. Synovial membrane cytokine expression is predictive of joint damage progression in rheumatoid arthritis: a twoyear prospective study (the DAMAGE study cohort). Arthritis Rheum 2006;54:1122-31.

[21] Nakae S, Saijo S, Horai R, Sudo K, Mori S, Iwakura Y. IL-17 production from activated $\mathrm{T}$ cells is required for the spontaneous development of destructive arthritis in mice deficient in IL-1 receptor antagonist. Proc Natl Acad Sci USA 2003;100:5986-90.

[22] Nakae S, Nambu A, Sudo K, Iwakura Y. Suppression of immune induction of collagen-induced arthritis in IL-17-deficient mice. J Immunol 2003;171:6173-7.

[23] Bush KA, Farmer KM, Walker JS, Kirkham BW. Reduction of joint inflammation and bone erosion in rat adjuvant arthritis by treatment with interleukin-17 receptor IgG1 Fc fusion protein. Arthritis Rheum 2002;46:802-5.

[24] Lubberts E, Koenders MI, Oppers-Walgreen B, Van den Bersselaar L, Coenen-de Roo CJJ, Joosten LAB, Van den Berg WB. Treatment with a neutralizing anti-murine interleukin-17 antibody after the onset of collagen-induced arthritis reduces joint inflammation, cartilage destruction, and bone erosion. Arthritis Rheum 2004;50:650-9.

[25] Chabaud M, Lubberts E, Joosten L, Van den Berg W, Miossec P. IL17 derived from juxta-articular bone and synovium contributes to 
joint degradation in rheumatoid arthritis. Arthritis Res 2001;3:168-77.

[26] Lubberts E, Joosten LAB, Van de Loo FAJ, Van den Bersselaar L, Van den Berg WB. Reduction of interleukin-17-induced inhibition of chondrocyte proteoglycan synthesis in intact murine articular cartilage by interleukin-4. Arthritis Rheum 2000;43:1300-6.

[27] Dudler J, Renggli-Zulliger N, Busso N, Lotz M, So A. Effect of interleukin-17 on proteoglycan degradation in murine knee joints. Ann Rheum Dis 2000;59:529-32.

[28] Cai L, Yin JP, Starovasnik MA, Hogue DA, Hillan KJ, Mort JS, Filvaroff EH. Pathways by which interleukin 17 induces articular cartilage breakdown in vitro and in vivo. Cytokine 2001;16:10-21.

[29] Van Bezooijen RL, Van der Wee-Pals L, Papapoulos SE, Lowik CW. Interleukin 17 synergises with tumour necrosis factor alpha to induce cartilage destruction in vitro. Ann Rheum Dis 2002;61:870-6.

[30] Bezooijen R, Farih-Sips HC, Papapoulos SE, Lowik CW. Interleukin-17: a new bone acting cytokine in vitro. $\mathrm{J}$ Bone Min Res 1999;14:1513-21.

[31] Koenders MI, Kolls JK, Oppers-Walgreen B, van den Bersselaar L, Joosten LA, Schurr JR, Schwarzenberger P, van den Berg WB, Lubberts E. Interleukin-17 receptor deficiency results in impaired synovial expression of interleukin-1 and matrix metalloproteinases 3, 9, and 13 and prevents cartilage destruction during chronic reactivated streptococcal cell wall-induced arthritis. Arthritis Rheum 2005;52:3239-47.

[32] Miossec P. Interleukin-17 in rheumatoid arthritis. If $\mathrm{T}$ cells were to contribute to inflammation and destruction through synergy. Arthritis Rheum 2003;48:594-601.

[33] Lubberts E, Koenders MI, van den Berg WB. The role of T-cell interleukin-17 in conducting destructive arthritis: lessons from animal models. Arthritis Res Ther 2005;7:29-37.

[34] Attur MG, Patel RN, Abramson SB, Amin AR. Interleukin-17 upregulation of nitric oxide production in human osteoarthritis cartilage. Arthritis Rheum 1997;40:1050-3.

[35] Martel-Pelletier J, Mineau F, Jovanovic D, Di Battista JA, Pelletier JP. Mitogen-activated protein kinase and nuclear factor $\kappa \mathrm{B}$ together regulate interleukin-17-induced nitric oxide production in human osteoarthritic chondrocytes: possible role of transactivating factor mitogen-activated protein kinase-activated protein kinase (MAPKAPK). Arthritis Rheum 1999;42:2399-409.

[36] LeGrand A, Fermor B, Fink C, Pisetsky DS, Weinberg JB, Vail TP, Guilak F. Interleukin-1, tumor necrosis factor alpha, and interleukin17 synergistically up-regulate nitric oxide and prostaglandin E2 production in explants of human osteoarthritic knee menisci. Arthritis Rheum 2001;44:2078-83.

[37] Koenders MI, Lubberts E, Oppers-Walgreen B, van den Bersselaar L, Helsen MM, Kolls JK, Joosten LA, van den Berg WB. Induction of cartilage damage by overexpression of $\mathrm{T}$ cell interleukin-17A in experimental arthritis in mice deficient in interleukin-1. Arthritis Rheum 2005;52:975-83.

[38] Koenders MI, Lubberts E, van de Loo FA, Oppers-Walgreen B, van den Bersselaar L, Helsen MM, Kolls JK, Di Padova FE, Joosten LA, van den Berg WB. Interleukin-17 acts independently of TNF-alpha under arthritic conditions. J Immunol 2006;176:6262-9.

[39] Benderdour M, Tardif G, Pelletier JP, Di Battista JA, Reboul P, Ranger P, Martel-Pelletier J. Interleukin 17 (IL-17) induces collagenase-3 production in human osteoclastic chondrocytes via AP-1 dependent activation: differential activation of AP-1 members by IL17 and IL-1beta. J Rheum 2002;29:1262-72.

[40] Hymowitz SG, Filvaroff EH, Yin JP, Lee J, Cai L, Risser P, Maruoka M, Mao W, Foster J, Kelley RF, Pan G, Gurney AL, de Vos AM, Starovasnik MA. IL-17s adopt a cystine knot fold: structure and activity of a novel cytokine, IL-17F, and implications for receptor binding. EMBO J 2001;20:5332-41.

[41] Moseley TA, Haudenschild DR, Rose L, Reddi AH. Interleukin-17 family and IL-17 receptors. Cytokine Growth Factor Rev $2003 ; 14: 155-74$.
[42] Lubberts E, Joosten LAB, Chabaud M, Van den Bersselaar L, Oppers B, Coenen-de Roo CJJ, Richards CD, Miossec P, Van den Berg WB. IL-4 gene therapy for collagen arthritis suppresses synovial IL-17 and osteoprotegerin ligand and prevents bone erosion. J Clin Invest 2000;105:1697-710.

[43] Lubberts E, Joosten LA, van Den Bersselaar L, Helsen MM, Bakker AC, van Meurs JB, Graham FL, Richards CD, van Den Berg WB. Adenoviral vector-mediated overexpression of IL-4 in the knee joint of mice with collagen-induced arthritis prevents cartilage destruction. J Immunol 1999;163:4546-56.

[44] Lubberts E, Van den Bersselaar L, Oppers-Walgreen B, Schwarzenberger P, Coenen-de Roo CJJ, Kolls JK, Joosten LAB, Van den Berg WB. IL-17 promotes bone erosion in murine collagen-induced arthritis through loss of the RANKL/OPG balance. J Immunol 2003; 170:2655-62.

[45] Toy D, Kugler D, Wolfson M, Vanden Bos T, Gurgel J, Derry J, Tocker J, Peschon J. Cutting edge: interleukin 17 signals through a heteromeric receptor complex. J Immunol 2006;177:36-9.

[46] Rong Z, Cheng L, Ren Y, Li Z, Li Y, Li X, Li H, Fu XY, Chang Z. Interleukin-17F signaling requires ubiquitination of interleukin-17 receptor via TRAF6. Cell Signal 2007;19:1514-20.

[47] Honorati MC, Meliconi R, Pulsatelli L, Cane S, Frizziero L, Facchini A. High in vivo expression of interleukin-17 receptor in synovial endothelial cells and chondrocytes from arthritis patients. Rheumatology (Oxford) 2001;40:522-7.

[48] Kehlen A, Thiele K, Riemann D, Langner J. Expression, modulation and signalling of IL-17 receptor in fibroblast-like synoviocytes of patients with rheumatoid arthritis. Clin Exp Immunol 2002;127:539-46.

[49] Honorati MC, Bovara M, Cattini L, Piacentini A, Facchini A. Contribution of interleukin 17 to human cartilage degradation and synovial inflammation in osteoarthritis. Osteoarthritis Cartilage 2002;10:799-807.

[50] Hwang SY, Kim HY. Expression of IL-17 homologs and their receptors in the synovial cells of rheumatoid arthritis patients. Mol Cells 2005;19:180-4.

[51] Langrish CL, Chen Y, Blumenschein WM, Mattson J, Basham B, Sedwick JD, McClanahan T, Kastelein RA, Cua DJ. IL-23 drives a pathogenic $\mathrm{T}$ cell population that induces autoimmune inflammation. J Exp Med 2005;201:233-40.

[52] Harrington LE et al. Interleukin 17-producing CD4+ effector T cells develop via a lineage distinct from the $\mathrm{T}$ helper type 1 and 2 lineages. Nat Immunol 2005;6:1123-32.

[53] Park $\mathrm{H}$ et al. A distinct lineage of CD4 $\mathrm{T}$ cells regulates tissue inflammation by producing IL-17. Nat Immunol 2005;6:1133-41.

[54] Cua DJ et al. Interleukin-23 rather than interleukin-12 is the critical cytokine for autoimmune inflammation of the brain. Nature 2003;421:744-8.

[55] Murphy CA et al. Divergent pro- and anti-inflammatory roles for IL-23 and IL-12 in joint autoimmune inflammation. J Exp Med 2003;198:1951-7.

[56] Veldhoen M, Hocking RJ, Atkins CJ, Locksley RM, Stockinger B. TGF- $\beta$ in the context of an inflammatory cytokine milieu supports de novo differentiation of IL-17-producing $\mathrm{T}$ cells. Immunity 2006;24:179-89.

[57] Bettelli E et al. Reciprocal developmental pathways for the generation of pathogenic effector TH17 and regulatory T cells. Nature 2006;441:235-8.

[58] Mangan PR et al. Transforming growth factor- $\beta$ induces development of TH17 lineage. Nature 2006;441:231-4.

[59] Liang SC, Tan X-Y, Luxenberg DP, Karim R, Dunussi-Joannopoulos K, Collins M, Fouser LA. Interleukin (IL)-22 and IL-17 are coexpressed by Th17 cells and cooperatively enhance expression of antimicrobial peptides. J Exp Med 2006;203:2271-9.

[60] Mus AMC, Ferry Cornelissen F, Asmawidjaja P, Hendriks R, Lubberts E. IL-23 induces Th17 polarization in splenic T cells from type II collagen-immunized DBA-1 mice and is critical for Th17 specific IL-22 expression. Ann Rheum Dis 2007:OP0086. 
[61] Korn T, Bettelli E, Gao W, Awasthi A, Jager A, Strom TB, Oukka M, Kuchroo VK. IL-21 initiates an alternative pathway to induce proinflammatory $\mathrm{T}(\mathrm{H}) 17$ cells. Nature 2007;448:484-7.

[62] Zhou L, Ivanov II, Spolski R, Min R, Shenderov K, Egawa T, Levy DE, Leonard WJ, Littman DR. IL-6 programs T(H)-17 cell differentiation by promoting sequential engagement of the IL-21 and IL-23 pathways. Nat Immunol 2007;8:967-74.

[63] Infante-Duarte C, Horton HF, Byrne MC, Kamradt T. Microbial lipopeptides induce the production of IL-17 in Th cells. J Immunol 2000;165:6107-15.

[64] Aggarwal S, Ghilardi N, Xie MH, de Sauvage FJ, Guerne AL. Interleukin-23 promotes a distinct $\mathrm{CD} 4 \mathrm{~T}$ cell activation state characterized by the production of interleukin-17. J Biol Chem 2003;278:1910-4.

[65] Zheng Y, Danilenko DM, Valdez P, Kasman I, Eastham-Anderson J, Wu J, Ouyang W. Interleukin-22, a TH17 cytokine, mediates IL-23induced dermal inflammation and acanthosis. Nature 2007;445:648-51.

[66] Wilson NJ, Boniface K, Chan JR, McKenzie BS, Blumenschein WM, Mattson JD, Basham B, Smith K, Chen T, Morel F, Lecron JC, Kastelein RA, Cua DJ, McClanahan TK, Bowman EP, de Waal Malefyt R. Development, cytokine profile and function of human interleukin 17-producing helper $\mathrm{T}$ cells. Nat Immunol 2007;8:950-7.

[67] Ivanov II, McKenzie BS, Zhou L, Tadokoro CE, Lepelley A, Lafaille JJ, Cua DJ, Littman DR. The orphan nuclear receptor ROR $\gamma$ t directs the differentiation program of proinflammatory IL-17+ $\mathrm{T}$ helper cells. Science 2006;126:1121-33.

[68] Owyang AM et al. Interleukin-25 regulates type 2 cytokine-dependent immunity and limits chronic inflammation in the gastrointestinal tract. J Exp Med 2006;203:843-9.

[69] Batten M, Li J, Yi S, Kljavin NM, Danilenko DM, Lucas S, Lee J, de Sauvage FJ, Ghilardi N. Interleukin 27 limits autoimmune encephalomyelitis by suppressing the development of interleukin 17-producing T cells. Nat Immunol 2006;7:929-36.

[70] Van Hamburg JP, Mus AMC, De Bruyn M, Asmawidjaja P, De Vogel L, Hendriks R, Lubberts E. T cell specific overexpression of GATA-3 prevents Th17 polarization and protects against severe joint inflammation during experimental arthritis. Ann Rheum Dis 2007:OP0075.

[71] Sato W, Aranami T, Yamamura T. Cutting edge: Human Th17 cells are identified as bearing CCR2+CCR5- phenotype. J Immunol 2007;178:7525-9.

[72] Acosta-Rodriguez EV, Napolitani G, Lanzavecchia A, Sallusto F. Interleukins 1 beta and 6 but not transforming growth factor-beta are essential for the differentiation of interleukin 17-producing human $\mathrm{T}$ helper cells. Nat Immunol 2007;8:942-9.

[73] Annunziato F, Cosmi L, Santarlasci V, Maggi L, Liotta F, Mazzinghi B, Parente E, Fili L, Ferri S, Frosali F, Giudici F, Romagnani P, Parronchi P, Tonelli F, Maggi E, Romagnani S. Phenotypic and functional features of human Th17 cells. J Exp Med 2007;204:1849-61.

[74] Aarvak T, Chabaud M, Kallberg E, Miossec P, Natvig JB. Change in the Th1/Th2 phenotype of memory T-cell clones from rheumatoid arthritis synovium. Scand J Immunol 1999;50:1-9.

[75] Hirota K, Hashimoto M, Yoshitomi H, Tanaka S, Nomura T, Yamaguchi T, Iwakura Y, Sakaguchi N, Sakaguchi S. T cell selfreactivity forms a cytokine milieu for spontaneous development of IL17+ Th cells that cause autoimmune arthritis. J Exp Med 2007;204:41-7.

[76] Sato K, Suematsu A, Okamoto K, Yamaguchi A, Morishita Y, Kadono Y, Tanaka S, Kodama T, Akira S, Iwakura Y, Cua DJ, Takayanagi $\mathrm{H}$. Th17 functions as an osteoclastogenic helper $\mathrm{T}$ cell subset that links $\mathrm{T}$ cell activation and bone destruction. J Exp Med 2006;203:2673-82.

[77] Langrish CL, McKenzie BS, Wilson NJ, de Waal Malefyt R, Kastelein RA, Cua DJ. IL-12 and IL-23: master regulators of innate and adaptive immunity. Immunol Rev 2004;202:96-105.

[78] Kolls JK, Linden A. Interleukin-17 family members and inflammation. Immunity 2004;21:467-76.

[79] Lubberts E. The role of IL-17 and family members in the pathogenesis of arthritis. Curr Opin Investig Drugs 2003;4:572-7.

[80] Lard LR, Visser H, Speyer I, vander Horst-Bruinsma IE, Zwinderman AH, Breedveld FC, Hazes JM. Early versus delayed treatment in patients with recent-onset rheumatoid arthritis: comparison of two cohorts who received different treatment strategies. Am J Med 2001;111:446-51. 